\title{
Preceding to Employee Satisfaction and Turnover Intention
}

\author{
Muhammad Rizwan \\ Lecturer, Department of Management Sciences, \\ The Islamia University of Bahawalpur, Pakistan \\ Rizwan.arshad@iub.edu.pk
}

Ahsan Mukhtar

Student, Department of Management Sciences, The Islamia University of Bahawalpur, Pakistan

Doi:10.5296/ ijhrs.v4i3.5876 URL: http://dx.doi.org/10.5296/ ijhrs.v4i3.5876

\begin{abstract}
As different research and studies have been conducted for the sake of understanding the concept of employee satisfaction but still organizations are incapable to find those factors that affect mostly on Satisfaction level of Employee. The main purpose of this research is to sort out those factors with intensity that mostly effect employee Satisfaction. Particularly, we took workplace environment, employee empowerment and pay \& promotion as the main variables to check their impact on employee satisfaction and further the impact of employee satisfaction on employee turnover. A questionnaire was developed for the purpose of collecting data to understand the level of employee satisfaction in different organizations. Convenient sampling was used to collect the data and 150 questionnaires were filled from the employees of different sectors. Statistically, the relationship of employee empowerment and workplace environment with employee satisfaction has significant results, but the relationship between pay and promotion and employee satisfaction was somewhat insignificant. Moreover, there was a significant effect of employee satisfaction on turnover intention of employees. This study will help the organizations to understand completely about the satisfaction level of employees and how they can motivate their employees to perform their job efficiently and effectively.
\end{abstract}

Keywords: Employees motivation, satisfaction, turnover 


\section{Introduction}

Employee satisfaction plays a vital role in defining the success of organizations. Employee satisfaction is considered weighty when it comes to define success of any organization. Satisfaction of Employee is most important particularly in the service industry. The enhancement of employee satisfaction is critical because it is a key to business success of any organization. It is basic need for a company to perceive as to what employees want, desire regarding workplace environment and devotion can be enhance.

A successful organizations tried to discover that there is a great degree of communication, assurance, employee satisfaction and temptation levels among its staff so that they would be more incentivized towards their work responsibilities and achieving overall organizational goals. Under these circumstances, the performance level of the employee rises to peak and the employer shows readiness to further enhance the facilities and benefits of the employees. There must be high spirit among intelligent workers can be of great benefit to any company because satisfied workers can produce more and stay loyal to the company. There are lot of factors involved in improving and maintaining the satisfaction of employees.

Mostly organizations in the world conduct surveys and interviews to know about the level of satisfaction of employees and gain information about the attitude towards their work. Both of these methods are acceptable, so for the sake of better understanding more reliable option should be selected. On the other side, there are the options of surveys that allow the respondents to give a more clear view. Interviews may have favored results, as the employees have fear about the consequences of saying any negative word about their firm or the supervisor.

The main purpose of our study is to know about the factors that affect the satisfaction level of an employee in a firm how much they affect. Particularly, we took employee empowerment, workplace environment and pay \&promotion as the independent variables to see their effect on the satisfaction level of employees and further their effect on the turnover intention of employees. The main area of this research is to find the level of satisfaction and helps organization to know about the factors that influence the level of satisfaction.

An organizational behavior is the main determinant of job satisfaction. If an employee is satisfied toward his organization or with his supervisor then he can work more deeply, devotedly and with more sincerity. The policies of the companies also focuses on the satisfaction level of employee not employee loyalty.

As far as our view is concerned, employee satisfaction assists a company to keep the sales on regularity and enhance the yield by employee appreciation.

The main focus of this research study is to find the major factors that help to develop the interest of the employees toward their job. As the study of Human Resource Management is the basic objective of any organization, therefore studying human resource helps the managers to know about the barriers that stop an employee to perform their duties properly and what are those factors, which motivate the employees. On the other hand, employee satisfaction focuses at salary, Law and justice and safety precautions of job, individual 
efforts, work load pressure, balance between working hours and personal life and capability to handle organization's way. Mostly employees are satisfied with the pay structure, promotion plan, facilities, Behavior towards immediate boss etc.

It is a common belief that the employee will give out his best if the employer provides his employee the peaceful work, reasonable wages and conductive environment. A successful organization always tries to find those factors under these the level of performance of the employee rises to amazing heights and the organizational employer shows enhance the benefits of the employees.

\section{Literature Review}

\section{Employee's Satisfaction}

It is commonly belief that satisfaction level of Employees is related with the perception and consideration about their job (Spector, 1997). There are a lot of presumptions concerning the causal relationship between motives, behavior and proceeds. The general feeling of an employee about its workplace and job is measurable by employee satisfaction. It measures his behavior and attitude towards the job and the degree of fulfilling the employee's needs towards job. As researchers concluded that, the satisfaction level of employees is used to measure the intentions of an employee towards their workplace. Many other factors have been determined by the researchers like hygiene factors, workplace environment and managerial responsibility based on different theories.

In literature, a number of researches have been done for the sake of satisfaction level of employees. The most important is the Maslow's hierarchy of need. According to the theory, he suggests that needs of individual starts from the basic ground needs (food, cloth and shelter) and ends at the level of self-actualization. Researchers approached to find the factors that affecting the level of satisfaction of employee totally based on the theory of necessity (Yousaf et al., 2013).

The Satisfaction level of employees is necessary for the sake of success of any business. Where employees are more satisfied there seems lower turnover rate. Therefore, employee's satisfaction is the most preferable for every employer. Whereas this is an commonly fact in management practices, whenever employers ignores the satisfaction needs of employees the downturn in a business comes. There are a number of reasons that enforce the employees to resign an organization it includes high responsibilities, low empowerment, low appreciation, limited chance of growth, or poor communication with the immediate supervisor. Managers should deeply observe these factors to decrease the rate of turnover, they should observe the working attitude of their employees, and if they find any derivational element in the employees, they must call the explanation regarding the issue for the sake of improving employee performance. This study is focuses on employee empowerment that has effect on satisfaction level of employees. Whether or whether not workplace environment has any effect on satisfaction of employees? Is there having any relationship of pay \& promotion with employee satisfaction? How turnover intention can be affected by employee satisfaction? 


\section{Macrothink}

International Journal of Human Resource Studies

ISSN 2162-3058

2014, Vol. 4, No. 3

Employee satisfaction's definition has been anticipated in literature as multiple theories. For instance, Herzberg's (1968) theory explained that the factors that create employee satisfaction are different from the factors that create dissatisfaction.

\section{Relationship of Empowerment on Employee Satisfaction}

Employee empowerment includes that to what extent employees have power in decision making in their daily activities. (Carless, 2004; Haas, 2010). The sharing of power with your sub ordinate is empowerment which is basically related to motivation and self-confidence among the employees (Hales and Klidas;1998) As empowerment of the employees is fully linked with the methods and techniques of organizations, such as communication, confidence, motivation, employee participation, training and feedback etc.

The authorization of worker covers the circle of routine activities which are undertaken according to its inside routine practices which totally effect of employee satisfaction. The authority of individual to control some activities and shared to administrative authorities (Michailova, 2002; Rizwan et al., 2013). Such practices can lead the performance of employees.

\section{H1: Empowerment has positive relation with Employee Satisfaction.}

\section{Relationship between Pay \& Promotion and Employee Satisfaction}

The satisfaction level is influenced with the level of benefits and pay and promotion system. The company must make best policies for the satisfaction of their employees to achieve goals. The employees can be motivated through pay, allowances and promotion. The higher the productivity of the organization, the lesser the employee turnover rate will be. The compensation is a term defined as the benefits received by employee from employer against services. The reward is found as the top best factor that effects on employee satisfaction. The opportunities of promotion also influence the employee performance with highly increase . The increments on salary of employee shows their importance for organization. An employee should be awarded incentives according to his/her performances. The previous practice shows the increase in wage rate will enhance satisfaction level and motivate an employee. (Wiens-Tuers 2002).

It is significant to note that reward is a very important instrument to control employee turnover rate. It also motivates the commitment of organizational employees which attracts employees toward their job.

\section{H2: Pay \& Promotion has a positive relation with employee satisfaction.}




\section{Macrothink \\ International Journal of Human Resource Studies \\ ISSN 2162-3058 \\ 2014, Vol. 4, No. 3}

\section{Relationship between Workplace Environment and Employee Satisfaction}

Workplace environment includes the location of the work, where the employee performs his work and daily activities. Workplace environment have both impact on employees either positive or negative on the satisfaction level of employees depending upon the nature of working environment. If the environment is comfortable then employee can perform better. The performance of an employee is directly proportional to the workplace environment. Employee satisfaction plays a vital role in the success of organization. If the physical working environment is pleasant then the employees will perform better. There are various aspects of the physical environment satisfaction that includes in employee's satisfaction. Research shows the high level of satisfaction with workplace environment has low level of turnover. When an employee is given higher level of satisfaction then it reduces turnover. (Dole and Schroeder, 2001). Carlopio (1996) found that satisfaction with workplace is positively related with job and reduce turnovers for better future.

The good physical environmental affects perception, feelings and satisfaction of job. The current workplace environment of various organizations has positive links with satisfaction of employees.

\section{H3: Satisfactory workplace environment has positive impact on Employee Satisfaction.}

\section{Relationship between Turnover Intention and Employee Satisfaction}

To accomplish the study objectives, the turnover intention is taken in a sense to be as leaving the job or department (Tett \& Meyer, 1993). Previous researches developed a great model that identifies the best reasonable translator of the behavior of individual to be reported.The behavior of employee is mostly depends upon the income of employee and work load. Some scholars thought, personal behavior is the single best predictor and estimator of turnover. ( Lee \& Mowday, 1987).

Whenever employee is satisfied there is the negative relation with employee turnover intentions but when employee is deprive from their rights there is high positive relation with turnover intentions which force employee to discontinue his job(Trevor, 2001). As practically researcher observed that there is mostly negative relation with turnover.

\section{H4: Employee satisfaction is inversely proportional to the turnover intention.}




\section{Macrothink

\section{Proposed Model of the Research}

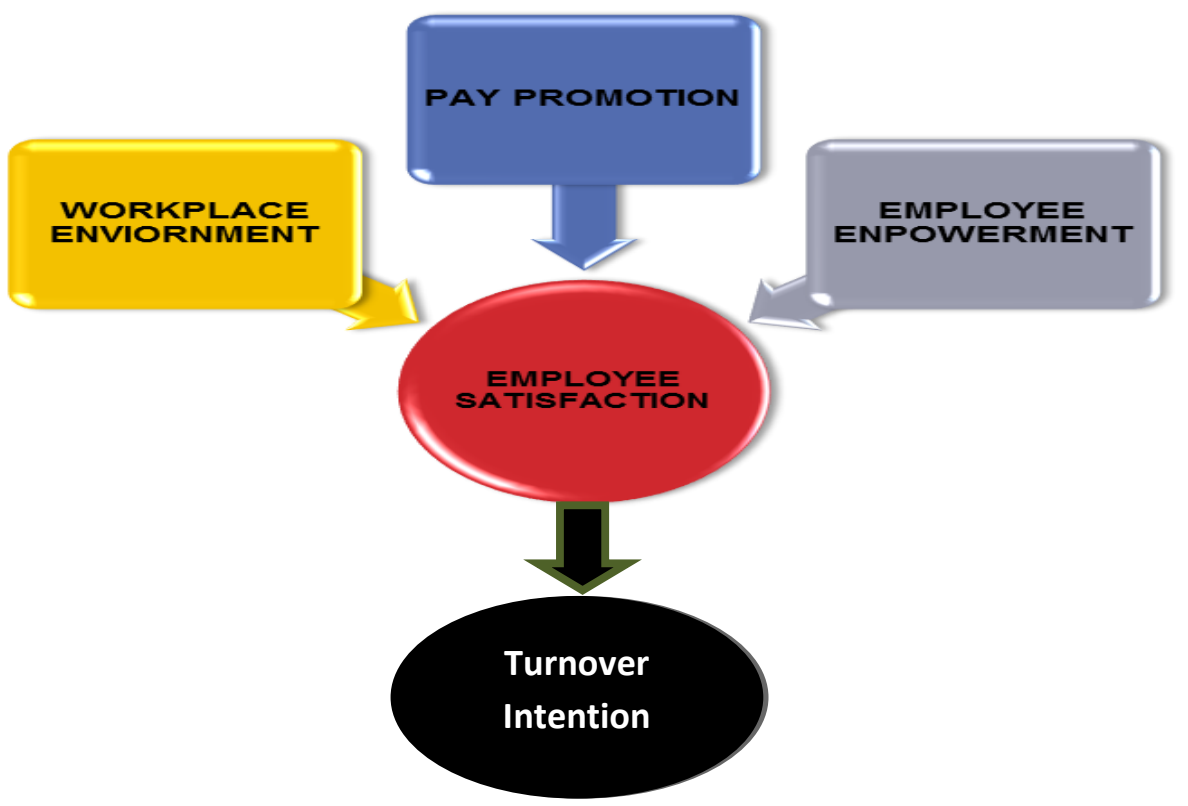

\section{Research Methodology}

The current research is descriptive in nature. Descriptive research can be explained as describing something, some phenomenon or any particular situation. Descriptive researches are those researches that describe the existing situation instead of interpreting and making judgments (Creswell, 1994). The main objective of the descriptive research is verification of the developed hypothesis that reflects the current situation. This type of research provides information about the current scenario and focus on past and present, e.g. quality of life in a community or customer attitudes towards any marketing activity.

\section{Sample/Data}

In order to collect the data for understanding the employee satisfaction level in various organizations. A sample of 150 respondents will ask to participate in a self-administered questionnaire. The population for the current research is the employees from public sector and private sector organizations. The current study utilizes a non-probability sampling technique that is convenience sampling. Convenience sampling is sampling technique that obtains and collects the relevant information from sample or the unit of study that are conveniently available (Zikmund, 1997).

It has ensured that the sample members possess different qualification and different scale of jobs to participate in the self-administered survey. The sample member should be employees of organization; this identifies their satisfaction level with their job and turnover intention among them. We select these sample members from different organizations of Bahawalpur City (Punjab, Pakistan). Two main clusters were targeted to collect the sample data university employees and some private organizations in the city. 


\section{Al Macrothink}

\section{Instrument and Scales}

The survey instrument of the current study addresses two major purposes; first is to analyze the relationship of different variables in employee satisfaction, second to collect information about the different characteristics of the respondents that can be used to understand the variations in different categories. The survey instrument contains two sections, section one includes different personal and demographic variables. This section will obtain the respondents information about gender, age, income and education. Section 2 includes the latent variables that are important in the current study. These variables include employee empowerment, pay \& promotion, workplace environment, employee satisfaction and turnover intention. This section of the study is developed based on the past literature and already used questionnaires. The scales of the study were adopted from the previous literature and published studies. The first three variables of the study were employee empowerment, pay \& promotion and workplace environment. The items of these variables were taken from the researches of Hayes 1994, Kabir \& Parvin 2011 and Lee 2006 respectively. The next variable is employee satisfaction having three items taken from Hackman and Oldham, 1975 and the last variable is turnover intention having four items taken from Seashore et al., 1982.

\section{TABLE 1: SCALES OF STUDY}

\begin{tabular}{|c|c|c|c|}
\hline No. & Variables & Items & Reference \\
\hline \multirow{6}{*}{1.} & \multirow{5}{*}{$\begin{array}{l}\text { Empowerment } \\
\text { (EE) }\end{array}$} & $\begin{array}{l}\text { I have the authority to correct customer problems } \\
\text { when they occur }\end{array}$ & \multirow{5}{*}{ Hayes, 1994} \\
\hline & & $\begin{array}{l}\text { I am encouraged to handle customer Problems by } \\
\text { myself. }\end{array}$ & \\
\hline & & $\begin{array}{l}\text { I am allowed to do almost anything to solve } \\
\text { customer problems. }\end{array}$ & \\
\hline & & $\begin{array}{l}\text { I am encouraged to handle customer problems by } \\
\text { myself. }\end{array}$ & \\
\hline & & $\begin{array}{l}\text { I do not have to get management's approval before I } \\
\text { handle customer problems. }\end{array}$ & \\
\hline & & $\begin{array}{l}\text { I am satisfied with the existing salary structure of } \\
\text { the company }\end{array}$ & Parvin \\
\hline
\end{tabular}




\begin{tabular}{|c|c|c|c|}
\hline \multirow[b]{2}{*}{2.} & \multirow{2}{*}{$\begin{array}{l}\text { Pay \& } \\
\text { Promotion } \\
(\mathrm{PP})\end{array}$} & $\begin{array}{l}\text { I am satisfied with the compensation I get and I } \\
\text { think it matches with my responsibility }\end{array}$ & \multirow[t]{2}{*}{$\begin{array}{l}\text { Kabir, } \\
2011\end{array}$} \\
\hline & & Everyone has an equal chance to be promoted & \\
\hline \multirow{4}{*}{3.} & \multirow{4}{*}{$\begin{array}{l}\text { Workplace } \\
\text { Environment }\end{array}$} & $\begin{array}{l}\text { The quality of my equipment is more than sufficient } \\
\text { to work effectively. }\end{array}$ & \multirow{4}{*}{ Lee, 2006} \\
\hline & & $\begin{array}{l}\text { I am able to be easily accessed from my colleague's } \\
\text { workstation. }\end{array}$ & \\
\hline & & $\begin{array}{l}\text { My workplace provides an undisturbed environment } \\
\text { so that I can concentrate on my work. }\end{array}$ & \\
\hline & & $\begin{array}{l}\text { I am able to control temperature or airflow in my } \\
\text { office. }\end{array}$ & \\
\hline \multirow{3}{*}{4.} & \multirow{3}{*}{$\begin{array}{l}\text { Turnover } \\
\text { Intention }\end{array}$} & $\begin{array}{l}\text { You are very likely to stay in this company for the } \\
\text { next five years }\end{array}$ & \multirow[t]{3}{*}{$\begin{array}{l}\text { Seashore et } \\
\text { al., } 1982\end{array}$} \\
\hline & & You will not give up this company easily. & \\
\hline & & $\begin{array}{l}\text { For you, this company is the best of all possible } \\
\text { organizations to work for. }\end{array}$ & \\
\hline \multirow{3}{*}{5.} & \multirow{3}{*}{$\begin{array}{l}\text { Employee } \\
\text { Satisfaction }\end{array}$} & Your work environment is pleasant & \multirow{3}{*}{$\begin{array}{l}\text { Hackman } \\
\text { and Oldham, } \\
1975\end{array}$} \\
\hline & & Overall, I am satisfied in my current practice & \\
\hline & & $\begin{array}{l}\text { If I had it to do it all over again, I'd still choose to } \\
\text { work where I do now }\end{array}$ & \\
\hline
\end{tabular}

\section{Procedure}

The questionnaire was distributed among 170 respondents in Bahawalpur City before giving the questionnaire. The purpose of study and questions were explained to the respondents so they can easily fill the questionnaire with relevant responses. 150 questionnaires were selected and rests of the questionnaires were not included in the further analysis due to 


\section{Macrothink}

International Journal of Human Resource Studies

ISSN 2162-3058

2014, Vol. 4, No. 3

incomplete or invalid responses. After collecting the completed questionnaires, these questionnaires were coded and entered into SPSS sheet for further regression analysis.

\section{Reliability Analysis}

Overall cronbach alphas of all variables in our study are more than acceptable and recommended value 0.50 by Nunnally (1970) and 0.60 by Moss el. al. (1998). This shows that all the 18 items were reliable and valid to measure the opinion of employees towards their satisfaction.

TABLE 2: RELIABILITY ANALYSIS

\begin{tabular}{|l|l|l|}
\hline Scales & Items & $\begin{array}{l}\text { Cronbach } \\
\text { Alpha }\end{array}$ \\
\hline Employee Empowerment & 5 & .547 \\
\hline Pay \& Promotion & 3 & .633 \\
\hline Workplace Environment & 4 & .648 \\
\hline Employee Satisfaction & 3 & .610 \\
\hline Turnover Intention & 3 & .621 \\
\hline
\end{tabular}

\section{Results and Analysis}

\section{Profile OF the Respondents}

Personal and demographic information includes gender, age, income and education level are presented in the following table.

TABLE 3: PROFILE OF THE RESPONDENTS

\begin{tabular}{|l|l|l|l|}
\hline & Categories & Frequency & Percent \\
\hline Gender & Male & 120 & 80.0 \\
\hline
\end{tabular}




\begin{tabular}{|c|c|c|c|}
\hline & Female & 30 & 20.0 \\
\hline & Total & 150 & 100.0 \\
\hline \multirow[t]{6}{*}{ Age } & Below & 18 & 1.7 \\
\hline & $18-25$ & 38 & 25.3 \\
\hline & $25-35$ & 51 & 34.0 \\
\hline & $35-45$ & 35 & 23.3 \\
\hline & 45 and above & 25 & 16.7 \\
\hline & Total 150100.0 & 150 & 100.0 \\
\hline \multirow{6}{*}{$\begin{array}{l}\text { Education } \\
\text { Level }\end{array}$} & Metric & 10 & 6.7 \\
\hline & Intermediate & 14 & 9.3 \\
\hline & Graduation & 44 & 29.3 \\
\hline & Master & 75 & 50.0 \\
\hline & M.Phils./PhD & 7 & 4.7 \\
\hline & Total & 150 & 100.0 \\
\hline \multirow{6}{*}{$\begin{array}{l}\text { Income } \\
\text { Level }\end{array}$} & Below 15000 & 27 & 18.0 \\
\hline & $15001-30000$ & 55 & 36.7 \\
\hline & $30001-45000$ & 40 & 26.7 \\
\hline & 45001 and above & 26 & 17.3 \\
\hline & 5 & 2 & 1.3 \\
\hline & Total & 150 & 100 \\
\hline
\end{tabular}




\section{Hypothesis Testing}

\subsubsection{Employee Empowerment \& Employee Satisfaction}

According to the result of the study employee empowerment (EE) has a significant positive association with employee satisfaction(ES) with $\beta=0.284$ and $\mathrm{P}<0.031$ that means the EE contributes to more than $28 \%$ to ES.

\subsubsection{Pay \& Promotion \& Employee Satisfaction}

According to the result of the study, Pay \& Promotion (PP) has a positive significant relationship with ES with $\beta=0.306$ and $\mathrm{P}<0.05$ thatmeans the PP contributes to more than $30 \%$ to ES.

\subsubsection{Workplace Environment \& Employee Satisfaction}

According to the result of the study workplace environment (WPE) has a significant positive association with ES with $\beta=0.268$ and $\mathrm{P}<0.01$ that means the WPE contributes to more than $26 \%$ to ES.

\subsubsection{Employee Satisfaction \& Turnover Intention}

According to the result of the study employee satisfaction (ES) has a significant positive relationship with Turnover Intention (TI)with $\beta=0.423$ and $\mathrm{P}<0.01$ that means the ES contributes to more than $42 \%$ to TI. 


\section{Macrothink

TABLE 4: REGRESSION RESULTS

\begin{tabular}{|l|l|l|l|l|l|l|}
\hline & & & & & \\
\\
H1
\end{tabular}




\begin{tabular}{|l|l|l|l|l|l|l|}
\hline ES & & & & & \\
\hline & & & & & & \\
\hline
\end{tabular}

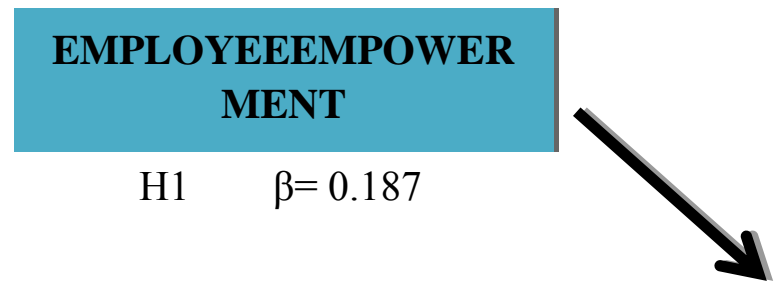

$$
\mathrm{R}^{2}=0.311
$$

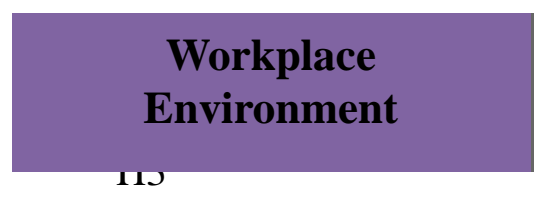

$\beta=0.177$

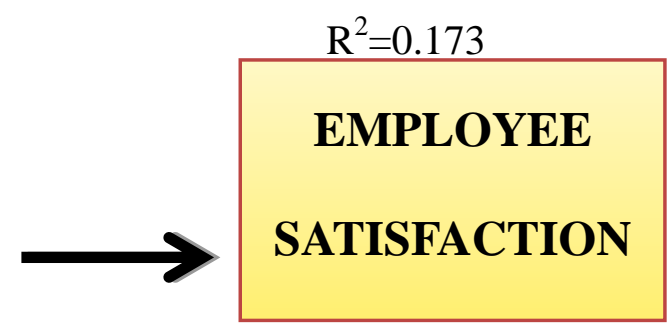

$$
\beta=0.423
$$

\section{PAY \& PROMOTION}

$\mathrm{B}=0.309$

$\mathrm{H} 2$

Figure 2. Regression results of the Model 


\section{Discussion}

This research has been conducted in the private sector as well as in public sector organizations of Bahawalpur City. The main objective of this research is to know the anticipants that have effect on employee satisfaction in any organization. We analyze many of past researches and choose the variables from that research papers to find their effect on the organizations in Bahawalpur City. This research also ensures that is there any correlation in employee satisfaction and employee turnover intention? We conducted this research by taking the sample of 170 employees from target population. 150 of the employees responded to our questionnaire. Our research consists of two parts, in the first part, we use employee empowerment, pay and promotion and workplace environment as independent variables and employee satisfaction as a dependent variable. In the second part, we took employee satisfaction as independent variable and turnover intention as a dependent variable. We conducted analysis on the data collected from the samples. The results show that EE has a significant positive relationship and it contributes more than $28 \%$ to ES. Therefore, when an employee is given autonomy in business decisions then his satisfaction level will rise. Similarly, PP has a positive relation with ES and it contributes less than $30 \%$ to ES. As it has a negative impact on employee satisfaction, it means that besides pay and promotion there are other more influential factors on employee satisfaction. Our next variable is workplace environment, according to the result of the study WPE has noteworthy positive relationship ES contributing more than $26 \%$ to ES. It shows that when an employee is given favorable and clean environment then its satisfaction level rises. In the second part of our research, paper we analyze the relationship between employee satisfaction and employee turnover intentions means intention towards leaving the organization. Whenever there is low level of employee satisfaction in any organization, the employees of that organization will intentionally leave that organization. According to the result of the study, ES has a significant positive relationship with TI contributing more than $42 \%$ to TI.

\section{Limitations and Future Researches}

The limitation of the study was that we had a very small sample size as well as a confined geographical area. So if the sample size and area of study is increased then the results will be more significant and accurate. We used convenient sampling technique but other sampling techniques can also be used. Several managerial implications emerge from this study by combining the theoretical perspective that examines employee satisfaction on the basis of employee empowerment, pay \& promotion and workplace environment. This study helps managers that what factors create satisfaction for an employee, and how they can increase the efficiency and effectiveness of an employee in an organization. Similarly other variables like teamwork, training and development, job security, employee performance, etc. can also be included in this study as past researches show that they have also significant influence over employee satisfaction. 


\section{References.}

[1] Spector, P. (1997), Satisfaction: Application, Assessment, Causes and Consequences, Sage, London.

[2] Locke, E. (1976), “The nature and causes of job satisfaction”, in Dunnette, M. (Ed.), Handbook of Industrial and Organizational Psychology, Rand McNally, Chicago,

IL, pp. 1297-349.

[3] Rainey, H.G. (1997), Understanding and Managing Public Organizations, 2nd ed., Jossey-Bass, San Francisco,CA.

[4] Le'vy-Garboua, L. and Montmarquette, C. (2004), "Reported job satisfaction: what does it mean?", Journal of Socio-Economics, Vol. 33, pp. 135-51.

[5] Cranny, C.J., Smith, P.C. and Stone, E.F. (1992), Job Satisfaction: How People Feel about Their Jobs and How It Affects Their Performance, Lexington, New

York, NY.

[6] Sweeney, A., Hohenshil, T. and Fortune, J. (2002), "Job satisfaction among employee assistance professionals", Journal of Employment Counselling, Vol. 39, pp. 52-60.

[7] Darrow, L.E. (1971), "Empirical test of the Herzbergt wo-factor theory of job satisfaction", unpublished doctoral dissertation, East Texas State University, Commerce, TX.

[8] Igalens, J. and Roussel, P. (1999), "A French comparative study of the relationships between compensation work motivation and job satisfaction of exempt and non-exempt employees", Working Paper No. 224(96-24), LIRHE, Unicersite Toulouse I, Toulouse.

[9] Kuo, H.T., Yin, T.J.C. and Li, I.C. (2007), "Relationship between organizational empowerment and job satisfaction perceived by nursing assistant at long-term care facilities", Journal of Clinical Nursing, Vol. 17, pp. 3059-66.

[10] Brewer, E.W., Lim, D.H. and Cross, M.E. (2008), "Job satisfaction and employee perception of the learning environment in the health care management industry", Journal of Leadership Studies, Vol. 1 No. 4, pp. 37-50.

[11] Ahsan, N., Abdullah, Z., Fie, D.Y.G. and Alam, S.S. (2009), “A study of job stress on job satisfaction among university staff in Malaysia: empirical study", European Journal of Social Sciences, Vol. 8 No. 1, pp. 121-31.

[12] Kuhlen, R.G. (1963), "Needs, perceived need satisfaction opportunities, and satisfaction with occupation”, Journal of Applied Psychology, Vol. XL VII No. 1, pp. 56-64.

[13] Conrad, K.M., Conrad, K.J. and Parker, J.E. (1985), "Job satisfaction among occupational health nurses", Journal of Community Health Nursing, Vol. 2, pp. 161- 73.

[14] Herzberg, F. (1968), Work and the Nature of Man, World Publishing, New York, NY. 


\section{Macrothink}

International Journal of Human Resource Studies ISSN 2162-3058 2014, Vol. 4, No. 3

[15] Petty, G.C., Brewer, E.W. and Brown, B. (2005), "Job satisfaction among employees of a youth development organization", child and Youth Care Forum, Vol. 34 No. 1.

[16] Carless, S.A. (2004), "Does psychological empowerment mediate the relationship between psychological climate and job satisfaction?", Journal of Business and Psychology, Vol. 18 No. 4, pp. 405-25.

[17] Haas, M.R. (2010), “The double-edged swords of autonomy and external knowledge: analyzing team effectiveness in a multinational organization", The Academy of Management Journal, Vol. 53, pp. 989-1008.

[18] Hales, C. and Klidas, A. (1998), "Empowerment in five-star hotels: choice, voice or rhetoric?”, International Journal of Contemporary Hospitality Management,

Vol. 10 No. 3, pp. $88-95$

.[19] Cunningham, I., Hyman, J. and Baldry, C. (1996), "Empowerment: the power to do what?", Industrial Relations Journal, Vol. 27 No. 2, pp. 143-54.

[20] Conger, J.A. and Kanungo, R.N. (1988), “The empowerment process: integrating theory and practice", Academy of Management Review, Vol. 13 No. 3, pp. 471- 82.

[21] Thomas, K.W. and Velthouse, B.S. (1990), "Cognitive elements of empowerment", Academy of Management Review, Vol. 15 No. 4, pp. 666-81.

[22] Baruch, Y. (1998), "Empowerment models in organizations", Career Development International, Vol. 3 No. 2, pp. 82-7.

[23] Trevor, C. O. (2001). Interactive effects among actual ease of movement determinants and job satisfaction in the prediction of voluntary turnover. Academy of Management Journal, $44,621-638$.

[24] March, J. G., \& Simon, H. A. (1958). Organizations. New York: Wiley.

[25] Sturman, M. C., Trevor, C. O., Boudreau, J. W., \& Gerhart, B. (2003). Is it worth it to win the talent war? Evaluating the utility of performance-based pay. Personnel Psychology, 56 (4), 997-1036.

[26] Creswell, J. W. (1994). Research designs: Qualitative and quantitative approaches. Thousand Oaks, CA: Sage.

[27] Kumar, Ranjit, 2005, Research Methodology-A Stepby- Step Guide for Beginners, (2nd.ed), Singapore, Pearson Education.

[28] Zikmund, W.R., (1997), Business Research Methods (5th Ed.), The Dryden Press, Fort Worth, Texas

[29] Hayes, B.E. (1994), "How to measure empowerment", Quality Progress, February, pp. 68-78. 
[30] Kabir, M. M. N., (2011), Factors affecting employee job satisfaction of pharmaceutical sector, Australian Journal of Business and Management Research, Vol. 1 No. 9, pp.: 113-123.

[31] Lee, (2006), Expectations of employees toward the workplace and environmental satisfaction, Facilities, Vol. 24 No. 9/10, pp.: 343-353.

[32] Hackman, J.R. and Oldham, G.R. (1975), "Development of the job diagnostic survey", Journal of Applied Psychology, Vol. 60, pp. 159-70.

[33] Seashore, S.E., Lawler, E.E., Mirvis, P.H. and Cammann, C. (1982), Observing and Measuring Organizational Change: A Guide to Field Practice, Wiley, New York, NY.

[34] Nunnally, J. (1970). Introduction to Psychological Measurement. Toronto: McGraw-Hill Inc.

[35] Kim, S. (2002), "Participative management and job satisfaction: lessons for management leadership”, Public Administration Review, Vol. 62 No. 2, pp. 231-41.

[36] Spreitzer, G.M. and Mishra, A.K. (2002), “To stay or to go? Voluntary survivor turnover following on organizational downsizing”, Journal of Organizational Behavior, No. 23, pp. 707-29.

[37] Han, S.-S., Moon, S.J. and Yun, E.K. (2009), "Empowerment, job satisfaction, and organizational commitment: comparison of permanent and temporary nurses in Korea", Applied Nursing Research, Vol. 22, pp. 15- 20.

[38] Caudron, S. (1995), "Create an empowering environment”, Personal Journal, Vol. 74, pp. 28-36.

[39] Janssen, O., Schoonebeek, G. and Looy, V.B. (1997), "Cognitions of empowerment: the link between participative management and employees' innovative behavior", Gedrad en Organization, Vol. 10 No. 4, pp. 175-94.

[40] C,o"l, G. (2008), "Algilanan gu"c,lendirmenin is,go"ren performance u"zerindeki etkileri”, Dog us, University Dergisi, Vol. 9 No. 1, pp. 35-46.

[41] Locke, E.A. (1991), "The motivation sequence, the motivation hub, and the motivation core", Organizational Behavior and Human Decision Processes, Vol. 50, pp. 288-99.

[42] Bowen, D. and Lawler, E.E. (1992), "The empowerment of service workers: what, why, how, and when",

Sloan Management Review, Vol. 33 No. 3, pp. 31-9. [32] Chebat, J.C. and Kollias, P. (2000), "The impact of empowerment on customer-contact employees' role in service organizations", Journal of Service Research, Vol. 3 No. 1, pp. 66-82.

[43] Eccles, T. (1993), "The deceptive allure of empowerment", Long Range Planning, Vol. 26, pp. 13-21.

[44] Spreitzer, G.M., De Janasz, S.C. and Quinn, R.E. (1999b), "Empowered to lead: the role of psychological empowerment in leadership", Journal of Organizational Behavior, Vol. 20, 
pp. 511-26.

[45] Bartunek, J.M. and Spreitzer, G.M. (2006), "The interdisciplinary career of a popular construct used in management - empowerment in the late 20th century", Journal of Management Inquiry, Vol. 15, pp. 255-73.

[46] Wilkinson, A. (1998), "Empowerment: theory and practice”, Personnel Review, Vol. 27, pp. 40-56.

[47] Michailova, S. (2002), "When common sense becomes uncommon: participation and empowerment in Russian companies with Western participation", Journal of World Business, Vol. 37, pp. 180-7.

[48] Robert, C., Probst, T.M., Martocchio, J.J., Drasgow, F. and Lawler, J.J. (2000), "Empowerment and continuous improvement in the United States, Mexico, Poland, and India: predicting fit on the basis of the dimensions of power distance and individualism", Journal of Applied Psychology, Vol. 85, pp. 643-58.

[49] Lovelock, C.H. (1992), Managing Services: Marketing, Operations, and Human Resources, Prentice-Hall, Upper Saddle River, NJ.

[50] Humborstad, S.I.W., Humborstad, B., Whitfield, R. and Perry, C. (2008b), "Implementation of empowerment in Chinese high power-distance organizations", The International Journal of Human Resource Management, Vol. 19, pp. 1349-64.

[51] Malhotra, N. and Mukherjee, A. (2003), "Analysing the commitment - service quality relationship: a comparative study of retail banking call centers and branches", Journal of Marketing Management, Vol. 19, pp. 941-71.

[52] Hancer, M. and George, R.T. (2003), "Psychological empowerment of non-supervisory employees working in full-service restaurants", International Journal of Hospitality Management, Vol. 22, pp. 3-16.

[53] Wiens-Tuers, B.A., \& Hill, E.T. (2002). Do they bother? Employer training of temporary workers. Review of Social Economy, 60(4), 543-566.

[54] Y. Kathawala, M. Kevin and E. Dean (1990) Preference between Salary or Job Security Increase. International Journal of Manpower. 11 (7).

[55] Zobal C (1998). The ideal team compensation system - an overview: Part I. Team Perform. Manage. 4(5): 235-249.

[56] Chiu, C.-H., Amemiya, C., Dewar, K., Kim, C.-B., Ruddle, F.H., and Wagner, G.P. (2002) Molecular evolution of the HoxA cluster in the three major gnathostome lineages. Proc. Natl. Acad. Sci. USA 99(8): 5492-5497.

[57] Moncarz E, Zhao J, Kay C (2009). An exploratory study of US lodging properties' organizational practices on employee turnover and retention, Int. J. Contemp. Hosp. Manage., 21(4): 437-458. 
[58] Cappelli, P. and Sherer, P. D. (1988). "Satisfaction, market wages \& labor relations: an airline study." Industrial Relations, Vol. 27 No. 1, 56-73.

[59] Clark, A. E., and Oswald, A. J. (1996). "Satisfaction and comparison income." Journal of Public Economics, Vol. 61, 359-381. [50] Chakrabarty S, Oubre DT, Brown G (2008). The impact of supervisory adaptive selling and supervisory feedback on salesperson performance. Ind. Mark. Manage., 37: 447-454

[50] Hammer mesh, D. S. (2001). "The changing distribution of job satisfaction." The Journal of Human Resources, Vol. 36 No. 1, 1-30.

[51] Dole, C. and Schroeder, R.G. (2001), "The impact of various factors on the personality, job satisfaction and turnover intentions of professional accountants", Managerial Auditing Journal, Vol. 16 No. 4, pp. 234-45.

[52] Carlopio, J.R. (1996), "Construct validity of a physical work environment satisfaction questionnaire”, Journal of Occupational Health Psychology, Vol. 1 No. 3, pp. 330-44.

[53] Sundstrom E., Town JP., Rice RW., March 1994, Osborn DP. and Brill M. Office noise, satisfaction and performance, Environment and Behavior, Vol 26, No. 2, 195-222.

[54] Leather, P., Beale, D. and Sullivan, L. (2003), "Noise, psychosocial stress and their interaction in the workplace", Journal of Environmental Psychology, Vol. 23 No. 2, pp. 213-22.

[55] Lee, S.Y. and Brand, J.M. (2005), "Effects of control over office workspace on perceptions of the work environment and work outcomes", Journal of Environmental Psychology, Vol. 25 No. 3, pp. 323-33.

[56] Tett, R.P. and Meyer, J.P. (1993), “Job satisfaction, organizational commitment, turnover intention, and turnover: path analysis based on meta-analytic findings", Personnel Psychology, Vol. 46, pp. 259-93.

[60] Fishbein M., \& Ajzen, I. (1975). Belief, attitude, intention, and behavior: An introduction to theory and research. Reading, MA: Addison-Wesley.

[61] Michael and Sector, (1982), Causes of Employee Turnover: A text of the Mohley, Griffeth, Hand and Meglino Model, Journal of Applied Psychology, 67, 53-59.

[62] Lee and Mowday, 1987, Voluntary leaving an organisation; an empirical investigation of Steers and Mowday's model of turnover, academy of management journal, 30, 721- 743.

[63] Abrams, D., Ando K., \& Hinkle S. (1998). Psychological attachment to the group: Cross-cultural differences in organizational identification and subjective norms as predictors of workers' turnover intentions. Personnel Social Psychology Bulletin, 24, 1027-1039.

[64] Muchinsky, P. M., \& Morrow, P. C. (1980). A multidisciplinary model of voluntary employee turnover. Journal of Vocational Behavior, 17, 263-290. 


\section{Macrothink \\ International Journal of Human Resource Studies \\ ISSN 2162-3058 \\ 2014, Vol. 4, No. 3}

[65] Trevor, C. O. (2001). Interactive effects among actual ease of movement determinants and job satisfaction in the prediction of voluntary turnover. Academy of Management Journal, 44, 621-638.

[66] March, J. G., \& Simon, H. A. (1958). Organizations. New York: Wiley.

[67] Sturman, M. C., Trevor, C. O., Boudreau, J. W., \& Gerhart, B. (2003). Is it worth it to win the talent war? Evaluating the utility of performance-based pay. Personnel Psychology, 56 (4), 997-1036.

[68] Creswell, J. W. (1994). Research designs: Qualitative and quantitative approaches. Thousand Oaks, CA: Sage.

[69] Kumar, Ranjit, 2005, Research Methodology-A Stepby- Step Guide for Beginners, (2nd.ed), Singapore, Pearson Education.

[70] Rizwan, M., Shahzad, N., Sheikh, Q., Batool, S., Riaz, M. \& Saddique, S. (2013) Variables that Have an Impact on Employee Satisfaction And Turnover Intention, International Journal of Research in Commerce, Economics and Management, 3(3), 131-138

[71] Younas, M., Rizwan, M., Khan, S., Majeed, Z., Khalid, S. \& Anjum, S. (2013) The Impact of Some Specific Factors on Employee Satisfaction: An Empirical Study from Pakistan. Journal of Basic and Applied Scientific Research, 3(12), 323-334 